\title{
TOWARDS AN EVER DIRTIER EUROPE? THE RESTRICTIVE STANDING OF ENVIRONMENTAL NGOS BEFORE THE EUROPEAN COURTS AND THE AARHUS CONVENTION
}

\begin{abstract}
Mariolina Eliantonio*
Summary: In European Union law, the existence of an effective remedy to challenge EU actions has been at the core of a heated ongoing debate, since individual applicants and NGOs often have a hard time obtaining locus standi in annulment proceedings, due to the restrictive interpretation given by the European Court of Justice to the standing requirements provided by (the former) Article 230(4) of the EC Treaty. The aim of this paper is to show how access to justice before the EU courts for environmental NGOs has been significantly curtailed up to the present, and to discuss the changes to the standing test brought by the Lisbon Treaty by analysing its content and the (to date) limited interpretation given by the European Courts to the term 'regulatory act' introduced by the Treaty. On the basis of this examination, it will be shown how the recent amendments have not changed the position of NGOs who wish to challenge EU environmental measures and how, therefore, a significant gap in judicial protection and a potential violation of Articles 9(2) and (3) of the Aarhus Convention still remain.
\end{abstract}

' $[\mathrm{P}]$ rovisions of the Treaty regarding the right of action of interested parties must not be interpreted restrictively ... the Treaty being silent on this point, a limitation in this respect may not be presumed."

\section{Introduction}

The right to an effective legal remedy is a generally accepted principle of modern legal systems and is enshrined in national constitutions as well as international treaties, such as the European Convention on Human Rights and Fundamental Freedoms. ${ }^{2}$

\footnotetext{
Assistant Professor of European Administrative Law and Academic Director of European Law School (English Language Track), Department of Public Law, Faculty of Law, Maastricht University.

1 The author of this quotation will be revealed at the end of the paper.

2 Arts 6 and 13 ECHR.
} 
At the EU level, the right to an effective remedy is laid down in Article 47 of the Charter of Fundamental Rights of the European Union. ${ }^{3}$ In European Union law, the existence of an effective remedy to challenge EU actions has been at the core of a heated ongoing debate, ${ }^{4}$ since individual applicants and NGOs often have a hard time obtaining locus standi in annulment proceedings. In particular, this is due to the restrictive interpretation given by the European Court of Justice to the standing requirements provided by (the former) Article 230(4) of the EC Treaty.

Consequently, many have argued that the right to an effective remedy against EU actions is not guaranteed in a sufficient way in the EU legal order. ${ }^{5}$

With specific regard to the challenge of EU environmental measures, one must also take the provisions of the Aarhus Convention into account. This international instrument was adopted by the European Community on 17 February 2005 by Decision 2005/370/EC 6 and provides, in

3 Article 47 of the Charter stipulates that 'everyone whose rights and freedoms guaranteed by the law of the Union are violated has the right to an effective remedy before a tribunal'.

4 For criticism on the standing requirements of individual applicants under Article 230 EC, see, ex multis, A Ward, 'Locus Standi under Article 230(4) of the EC Treaty: Crafting a Coherent Test for a Wobbly Polity' [2003] 22Yearbook of European Law 45; A Arnull, 'Private Applicants and the Action for Annulment since Codorniu' [2001] 38 CML Rev 7; JM Martin Cortés, 'Ubi ius, ibi Remedium? Locus Standi of Private Applicants under Article 230(4) EC at a European Constitutional Crossroads' [2004] 11Maastricht Journal of European and Comparative Law233; A Ward, 'Amsterdam and Amendment to Article 230: An Opportunity Lost or Simply Deferred?' in A Dashwood and A Johnston, The Future of the Judicial System of the European Union (Hart Publishing 2001) 37; A Abaquense de Parfouru, 'Locus Standi of Private Applicants under the Article 230 EC Action for Annulment: Any Lessons to be Learnt from France?' [2007] 14Maastricht Journal of European and Comparative Law 361; A Cygan, 'Protecting the Interests of Civil Society in Community Decision-making: The Limits of Article 230 EC' [2003] 52International and Comparative Law Quarterly 995; X Lewis, 'Standing of Private Plaintiffs to Annul Generally Applicable European Community Measures: If the System is Broken, where Should it be Fixed?'[2006-2007] 30 Fordham International Law Journal 1496. Specifically with regard to environmental policy, see for instance B Dette, 'Access to Justice in Environmental Matters: A Fundamental Democratic Right' in M Onida, Europe and the Environment. Legal Essays in Honour of Ludwig Krämer (Europa Law Publishing 2004) 1.

5 J Usher, 'Direct and Individual Concern: An Effective Remedy or a Conventional Solution?'[2005]28 ELR 575; F Ragolle, 'Access to Justice for Private Applicants in the Community Legal Order: Recent (R)evolutions' [2003] 28ELR90; A Albor-Llorens, 'The Standing of Private Parties to Challenge Community Measures: Has the European Court Missed the Boat?' [2003] 62 CLJ 72. Specifically with regard to environmental policy, see N Gérard, 'Access to Justice on Environmental Matters: A Case of Double Standards?' [1996] 140Journal of Environmental Law149; F Berrod, 'Comment to Greenpeace' [1999] 36 CML Rev635; N Gérard, 'Access to the European Court of Justice: A Lost Opportunity' [1998] 10 Journal of Environmental Law 338; DL Torrens, 'Locus Standi for Environmental Associations under EC Law - Greenpeace - A Missed Opportunity for the ECJ' [1999] 8Review of European Community \& International Environmental Law336.

6 Council Decision 2005/370/EC of 17 February 2005 on the conclusion, on behalf of the European Community, of the Convention on access to information, public participation in decision-making and access to justice in environmental matters [2005] OJ L 124/1. 
Article 9(2), that the contracting parties should ensure that members of the public having a sufficient interest or maintaining impairment of a right (where the administrative procedural law of a party requires this as a precondition) have access to a review procedure to challenge the substantive and procedural legality of decisions concerning activities subject to the public participation requirements of Article 6 of the Convention itself. Furthermore, Article 9(3) provides for the obligation of the parties to provide wide access for members of the public to review procedures to challenge the legality of decisions affecting the environment.

To apply the provisions of the Aarhus Convention to EU institutions and bodies, the European Community adopted Regulation No 1367/2006 (the Aarhus Regulation). ${ }^{7}$ Specifically with regard to non-governmental organisations, the Regulation allows those organisations which fulfil certain requirements ${ }^{8}$ to institute proceedings before the European Courts against the acts of EU institutions and the decisions of EU bodies. However, it expressly states that NGOs may do so only 'in accordance with the relevant provisions of the EC Treaty' (Article 12(1)). ${ }^{9}$

The aim of this paper is to show how access to justice before the EU courts for environmental NGOs has been significantly curtailed up to the present, and to discuss the changes to the standing test brought by the Lisbon Treaty by analysing its content and the (to date) limited interpretation given by the European Courts to the term 'regulatory act' introduced by the Treaty. On the basis of this examination, it will be shown how the recent amendments have not changed the position of NGOs who wish to challenge EU environmental measures and how, therefore, a significant gap in judicial protection and a potential violation of Articles 9(2) and (3) of the Aarhus Convention still remain.

\section{The limited standing of environmental NGOs before the European courts}

The action for annulment provided for in Article 263 of the Treaty on the Functioning of the European Union (TEFU) (formerly in Article 230 of

\footnotetext{
7 Regulation 1367/2006/EC of 25 September 2006 of the European Parliament and of the Council on the application of the provisions of the Aarhus Convention on Access to Information, Public Participation in Decision-making and Access to Justice in Environmental Matters to Community Institutions and Bodies [2006] OJ L 264/13. The Regulation entered into force on 28 September 2006 and started to apply from 17 July 2007.

8 Article 11 provides for certain criteria which must be fulfilled for NGOs to initiate an internal review procedure and action for annulment before the EU courts.

9 For a quite harsh criticism of this instrument, see J Jans, 'Did Baron von Munchhausen ever Visit Aarhus? Some Critical Remarks on the Proposal for a Regulation on the Application of the Provisions of the Aarhus Convention to EC Institutions and Bodies' in R Macrory, Reflections on 30 Years of EU Environmental Law: A High Level of Protection? (Europa Law Publishing 2006) 474.
} 
the EC Treaty) is the main mechanism for the judicial review of EU acts. This article provides that a natural or legal person may bring an action for annulment only in certain specific circumstances, namely in cases of challenges against 'decisions addressed to that person or against a decision which, although in the form of a regulation or a decision addressed to another person, is of direct and individual concern' to the applicant.

The first requirement, direct concern, is relatively straightforward compared to the requirement of individual concern. ${ }^{10}$ The ECJ has consistently found that a measure will be of direct concern to the applicant when the latter's legal position has been directly adversely affected. In other words, there must be a direct link between the challenged measure and the loss or damage that the applicant has suffered. ${ }^{11}$ Furthermore, the Court will, with a high likelihood, deem a causation chain to be broken if the contested EU measure leaves any discretion to the addressees of the measure who are responsible for its implementation. ${ }^{12}$

The second requirement is more problematic. The ECJ laid down its view on the requirement of individual concern in the Plaumann case, ${ }^{13}$ where the Court found that:

Persons other than those to whom a decision is addressed may only claim to be individually concerned if that decision affects them by reason of certain attributes which are peculiar to them or by reason of circumstances in which they are differentiated from all other persons and by virtue of these factors distinguishes them individually just as in the case of the person addressed. (emphasis added)

This landmark case thus set the threshold for admitting individual applicants very high by restricting the locus standi only to those persons who differentiate themselves from all other persons. ${ }^{14}$ In applying the Plaumann test, the Court has allowed standing to applicants only in

\footnotetext{
10 Albor-Llorens correctly notes that the lower profile of the test of direct concern is due to the fact that the ECJ has been less rigid and more consistent in the interpretation of this concept. Furthermore, since the tests of individual and direct concern are cumulative, the Court has frequently denied standing to private applicants on the grounds of lack of individual concern, without even considering the requirement of direct concern. Albor-Llorens (n 5) 75 .

11 Cases 41-44/70 International Fruit Company BV $v$ Commission [1971] ECR 411. In this case, employees of a merging company were not granted locus standi to challenge a Commission decision allowing the merger, due to the fact that possible employment terminations would not be the direct consequence of the Commission decision.

12 See, for example, Case69/69 Alcan Aluminium Raeren $v$ Commission[1970]ECR 385 andCase222/83 Municipality of Differdange v Commission[1984]ECR 2889.

13 Case 25/62 Plaumann \& Co $v$ Commission [1963] ECR 95.

14 When applied to the facts of the Plaumann case, this meant that, although the company in question was actually among the few companies importing clementines into the Community area, any person could potentially engage in such a business activity. Hence, the Court found that Plaumann was not individually concerned.
} 
exceptional circumstances, namely, where the applicant can show that it belongs to a so-called 'closed class' which is differently affected by the challenged measure compared to all other natural or legal persons. ${ }^{15}$

More specifically with regard to environmental NGOs, the Plaumann jurisprudence was asserted for the first time in the Stichting Greenpeace Council case. ${ }^{16}$ In this case, the Court of First Instance (CFI) held that the Plaumann test 'remains applicable whatever the nature, economic or otherwise, of those of the applicants' interests which are affected ${ }^{17}$ and did not set up an exception for environmental matters. By applying the Plaumann test, the CFI concluded that, since the applicant association did not 'adduce any special circumstances to demonstrate the individual interest of their members as opposed to any other person residing in those areas'18 and, therefore, '[T]he possible effect on the legal position of the members of the applicant associations cannot ... be any different from that alleged here by the applicants who are private individuals', ${ }^{19}$ standing had to be refused.

On appeal, the ECJ confirmed the judgment of the CFI in applying the Plaumann test. ${ }^{20}$ In particular, the ECJ was not convinced by the appellants' plea that:

by applying the case-law developed by the Court of Justice in relation to economic issues and economic rights, according to which an individual must belong to a 'closed class' in order to be individually concerned by a Community act, the Court of First Instance failed to take account of the nature and specific character of the environmental interests underpinning their action. ${ }^{21}$

\footnotetext{
15 For example, in a case concerning seven Greek cotton traders who sought a judicial review of a Commission decision that authorised France to impose a fixed-term quota on cotton yarn imports from Greece to France, the Court found that pre-existing import contracts differentiated the applicant from potential importers and thus granted standing to the applicants. See Case 11/82 Piraiki-Patraiki v Commission [1985] ECR 207. The 'closed class' test has attracted much criticism because of its formalistic and artificial nature. See, for example, A Arnull, 'Private Applicants and the Action for Annulment under Article 173 of the EC Treaty' [1995] 32CML Rev7, 44-49. For a thorough review of the case law, see Arnull (n 4).

16 Case T-585/93 Stichting Greenpeace Council (Greenpeace International) and Others $v$ Commission [1995] ECR II-2205. In this case, Greenpeace International, together with local associations and residents in Gran Canaria, were seeking the annulment of a decision adopted by the European Commission to disburse to the Kingdom of Spain a certain sum by way of financial assistance provided by the European Regional Development Fund for the construction of two power stations in the Canary Islands without first requiring or carrying out an environmental impact assessment.

17 Stichting Greenpeace Council (n 16) para 50.

18 Stichting Greenpeace Council (n 16) para 60.

19 Stichting Greenpeace Council (n 16) para 60.

20 Case C-321/95 P, Stichting Greenpeace Council (Greenpeace International) and Others $v$ Commission [1998] ECR I-1651.

21 Stichting Greenpeace Council (n 20) para 17.
} 
The CFI confirmed its position in the EEB and Stichting Natuur en Milieu case. ${ }^{22}$ In this case, the EEB, a federation of over 145 environmental citizens' organisations based in the 27 EU Member States, and Stichting Natuur en Milieu (SNM) sought the annulment of certain provisions of two decisions of the European Commission which allowed the Member States to maintain in force authorisations for the use of two herbicide products with potential negative effects on the environment and human health.

The CFI reasserted the Plaumann jurisprudence and considered that the European Commission's decisions affected the applicants in the same manner as any other person in the same situation, and that the fact that their purpose was the protection of the environment and the conservation of nature did not establish that they were individually concerned by the decisions. It also held that the special consultative status of the EEB and SNM with the European institutions did not support the finding that they were individually concerned by the contested decisions, as the Community legislation applicable to the adoption of the said decisions did not provide for any procedural guarantee for the applicants. This case was not appealed to the ECJ.

The $E E B$ case is important for two reasons. First of all, when the Court adopted its judgment, the Aarhus Convention was already in force in the European Community. The second reason is that the CFI refused to grant NGOs access to justice, since it considered that the proposal for the regulation that was to apply the provisions of the Aarhus Convention to the EC institutions and bodies (ie the Aarhus Regulation mentioned above) did not grant standing to environmental NGOs unless the latter met the 'individual concern' criterion as set out in Article 230 paragraph 4 of the EC Treaty.

After the entry into force of the Aarhus Regulation, the CFI did not change its jurisprudence and instead reasserted it forcefully in the WWF$U K$ case. ${ }^{23}$ In this case, WWF-UK, an environmental NGO, sought the annulment in part of a Council regulation fixing the fishing opportunities for certain fish stocks applicable in Community waters. The CFI once again concluded that WWF-UK was not individually concerned by the contested regulation in reasserting the Plaumann jurisprudence and dismissed the action. For the purposes of this paper, it is important to point out that the CFI stated that:

[A]ny entitlements which the applicant may derive from the Aarhus Convention and from Regulation No 1367/2006 [ie the Aarhus Regulation] are granted to it in its capacity as a member of the public.

\footnotetext{
22 Joined Cases T-236/04 and T-241/04 European Environmental Bureau (EEB) and Stichting Natuur en Milieu $v$ Commission [2005] ECR II-04945.

${ }^{23}$ Case T-91/07 WWF-UK Ltd $v$ Council [2008] ECR II-81.
} 
Such entitlements cannot therefore be such as to differentiate the applicant from all other persons within the meaning of [the Plaumann jurisprudence]. ${ }^{24}$

The Court thus applied the Plaumann test in the same way as it had done before, notwithstanding the approval of the Aarhus Convention by the European Community and the adoption of the Aarhus Regulation. Moreover, as in the $E E B$ case, neither the statutory aim of the applicant NGO to protect the environment, nor its special status allowing it to participate in the decision-making process of the contested regulation were criteria considered by the Court as giving the right to challenge the contested regulation.

On appeal, ${ }^{25}$ the ECJ confirmed the CFI's position and, in order to support its argument, made a distinction between substance and procedure, which cannot be found in the CFI's ruling. In particular, the ECJ agreed on the fact that if a person is involved in the procedure leading to the adoption of a Community measure, this person is capable of distinguishing him/herself individually in relation to the measure in question if the applicable Community legislation grants him certain procedural guarantees. However, that person enjoying such a procedural right will, in the ECJ's view, not have standing to bring proceedings contesting the legality of a Community act in terms of its substantive content.

According to the ECJ, the applicant association had the right to be heard by the Commission prior to the adoption of the contested Community measure. However, there was no obligation for the Community legislature to implement the proposals made in the recommendations. From this distinction, the ECJ derived the conclusion that the existence of a procedural guarantee before the Community judicature did not imply that the action was admissible, as it was based on pleas alleging the infringement of substantive rules of law.

The CFI confirmed this restrictive position in the Autonomous Region of the Azores case, ${ }^{26}$ in which the Autonomous Region sought the annulment in part of a regulation on the management of the fishing effort relating to Community fishing areas and resources. Three environmental associations, Seas at Risk, the WWF and Stichting Greenpeace Council sought leave to intervene in the case in support of the applicant.

In reply to the arguments of the applicant that Article 230(4) EC should be interpreted in such a way as to render it compatible with Article 9 of the Aarhus Convention, the Court held that the Convention had not

\footnotetext{
$24 \quad W W F-U K L t d$ (n 23) para 82.

25 Case C-355/08 P, WWF-UKv Council [2009] ECR I-73.

26 Case T-37/04 Região Autónoma dos Açores $v$ Council [2008] ECR II-103.
} 
been approved by the Community when the action was brought. In addition, it recalled that Article 9 of the Aarhus Convention refers expressly to 'the criteria, if any, laid down in [the] national law' of the contracting parties, and that those criteria were laid down, with regard to actions brought before the Community judicature, in Article 230 EC. Upon this basis, the Court dismissed the action, as it considered the applicant not to be individually concerned by the contested act under Article 230(4) EC.

The Court acknowledged that the Aarhus Regulation allows certain NGOs to bring an action for annulment before the Community judicature. However, the Court considered that the conditions laid down in the regulation were not satisfied in the present case, but did not give any explanation and further deemed that it is not for the Court to substitute itself for the legislature and to accept, on the basis of the Aarhus Convention, the admissibility of an action which does not meet the conditions laid down in Article 230 EC' ${ }^{27}$ The case was appealed to the ECJ, which dismissed the appeal without further discussing any point concerning the Aarhus Convention. ${ }^{28}$

\section{The case law of the European Courts and the Aarhus Convention}

The analysis of the relevant case law shows that, in reasserting the Plaumann jurisprudence in all cases concerning environmental matters, the European Courts have firmly refused to allow environmental NGOs to challenge decisions of EU institutions. In fact, the European Courts (the Court of First Instance and the European Court of Justice) have interpreted the individual concern criterion so narrowly (and, one could argue, somewhat paradoxically) ${ }^{29}$ that environmental NGOs have in every case been refused standing to challenge EU institutions' decisions, exempting essentially these decisions from judicial scrutiny.

Apart from the Greenpeace rulings, all the rulings examined above were rendered after the adoption of the Aarhus Convention by the EC. When the WWF-UK and Autonomous Region of the Azores judgments were rendered, not only was the Convention in force, but the Aarhus Regulation had been adopted. It should be noted, however, that WWF-UK is the only case initiated after the entry in force of the Aarhus Convention in the European Community, and that to date no ruling has been rendered in a case which was initiated after the entry into force of the Aarhus Regulation.

\footnotetext{
27 Região Autónoma dos Açores (n 26) para 93.

28 Case C-444/08 Região Autónoma dos Açores v Council [2009] ECR I-200.

29 The application of the Plaumann test to environmental measures has the perverse effect that the higher the number of individuals affected by EU measures (and hence, one could argue, the more potentially dangerous the EU measure is), the less chance there will be that standing will be granted.
} 
When the Court adopted its judgment in the EEB case, the Aarhus Convention was in force in the European Community. However, as it had not been in force when the action was initiated, the Court could not apply it. However, the Court could have been guided by the provisions and the spirit of the Convention to reconsider the standing rules and widen the access to justice for members of the public in the light of Article 9 of the Aarhus Convention.

The same could be argued with regard to the Autonomous Region of the Azores case, which was also rendered when the Aarhus Regulation was in force. In this case, the CFI recognised that the Community legislature adopted the Aarhus Regulation in order to facilitate access to the Community judicature in environmental matters', ${ }^{30}$ and that the Regulation 'lays down a procedure on completion of which certain NGOs may bring an action for annulment before the Community judicature under Article 230 EC'. ${ }^{31}$ However, the reference to the condition 'under Article 230 EC' and the CFI's indication that Article 9(3) of the Aarhus Convention mentions 'the criteria, if any, laid down in national law' removed any possibility of an action for annulment. The CFI, indeed, considered that by the 'criteria laid down in national law', the interpretation of 'individual concern' must also be included, to the effect that only the legislature could decide that Article 230 EC should be interpreted differently or could amend it.

In taking this position, however, the CFI did not acknowledge the findings and recommendations of the Compliance Committee of the Aarhus Convention concerning the Belgian Council of State, in which it stated that:

the Parties may not take the clause 'where they meet the criteria, if any, laid down in its national law' as an excuse for introducing or maintaining so strict criteria that they effectively bar all or almost all environmental organisations from challenging acts or omissions that contravene national law relating to the environment. ${ }^{32}$

The position of the CFI, therefore, cannot be accepted since it appears from all the case law cited that the criteria imposed by it are so strict that they bar all environmental organisations from challenging acts that are not in compliance with European law relating to the environment.

From the perspective of compliance with the Aarhus Convention, the outcome of the WWF-UK case is even more worrying, because it de-

30 Case C-444/08 Região Autónoma dos Açores (n 28) para 93.

31 Case C-444/08 Região Autónoma dos Açores (n 28) para 93.

32 Findings and recommendations of the Aarhus Compliance Committee with regard to compliance by Belgium with its obligations under the Aarhus Convention in relation to the rights of environmental organisations to have access to justice, ECE/MP.PP/C.1/2006/4/ Add.2, 28 July 2006 (para 35). 
monstrates that the CFI and the ECJ continued to apply the Plaumann test notwithstanding the fact that the case was initiated after the entry into force of the Aarhus Convention. According to Article 9(2) of the Aarhus Convention, members of the public concerned do not have to have a special consultative status, as WWF-UK had, to have standing in order to challenge a decision: they must either have a sufficient interest or maintain an impairment of a right. It could be argued that because of its statutory aim and special position in the decision-making leading to the adoption of the measure it was challenging, WWF-UK had a sufficient interest.

The decision of the CFI is, therefore, not in compliance with Article 9(2) of the Aarhus Convention, which provides that:

what constitutes a sufficient interest and impairment of a right shall be determined in accordance with the requirements of national law and consistently with the objective of giving the public concerned wide access to justice.

The same can be argued with regard to the ECJ's ruling in the appeal case. Here the ECJ seemed to acknowledge that an environmental NGO which is involved in a consultative status in the process of the decisionmaking leading to the adoption of an EC measure could be regarded as having individual concern. However, the ECJ specified that, in that case, the NGO would be regarded as having individual concern only with regard to procedural failures and not with regard to the legality of the measure in terms of its substantive content. While this ruling could be regarded as opening the door to environmental NGOs, one immediately sees how this concession is merely formal. The only consequence it could have is to admit a challenge on procedural grounds (eg lack of consultation of an NGO which should have been consulted), but it would never provide the basis for a substantive challenge to an EU environmental measure.

This position is at odds with Article 9(2) of the Aarhus Convention, which prescribes access to justice for members of the public concerned to challenge the substantive and procedural legality of a decision affecting the environment.

In general, it can be concluded that the European Courts seem to have ignored the requirements mandated by the Convention, since they have interpreted the criteria laid down in Article 230 EC so strictly that they bar all environmental organisations from challenging acts relating to the environment which are not in compliance with European law. This interpretation by the European Courts of the requirement of individual concern provided for in Article 230 EC does not seem to comply with the requirements of Article 9(2) and (3) of the Aarhus Convention, since the consequences of applying the Plaumann test to environmental and health 
issues is that in effect no NGO is ever able to challenge an environmental measure before the European Courts.

It is worth noting that the ECJ has on several occasions justified this restrictive approach to the standing of private applicants in annulment actions by referring to the idea of a 'complete system of remedies' created by the EC Treaty. ${ }^{33}$ In the ECJ's view, this system is complete because an EU measure may be challenged either through a direct action under the former Article 230 EC (now Article 263 TFEU) or through the preliminary ruling procedure pursuant to the former Article $234 \mathrm{EC}$ (now Article 267 TFEU). Hence, according to the ECJ, a restrictive interpretation of 'individual concern' does not create a gap in judicial protection, because individuals have the option to bring actions against the national implementation measures of EU measures before the national courts, which creates the obligation, pursuant to Article 267 TFEU and the ECJ's ruling in Foto-Frost, ${ }^{34}$ to refer questions of validity of EU measures to the ECJ. ${ }^{35}$ However, for all the reasons highlighted by AG Jacobs in the UPA case, ${ }^{36}$ an indirect challenge to EU measures at the national level may not be regarded as an adequate substitute for a direct action before the European judicature, and may result in a complete denial of a remedy or in the denial of an effective remedy. ${ }^{37}$

The first situation arises when the contested EU measure does not require any implementing act at the national level. In this situation, the only way for the applicants to have access to a court would be to violate the rules laid down in the contested EU measure and rely on the invalidity of this measure in domestic proceedings. It has been considered that this option is theoretically possible, but cannot be sustained in a Union based on the rule of law. ${ }^{38}$ As AG Jacobs put it, individuals 'cannot be required to breach the law in order to gain access to justice'. ${ }^{39}$ Hence, in such situations, the ECJ's reliance on the preliminary ruling proceedings would result in a complete lack of judicial protection.

33 Case 294/83 Parti Ecologiste 'Les Verts' v European Parliament [1986] ECR 1339.

34 Case 314/85 Foto-Frost v Hauptzollamt Lübeck-Ost [1987] ECR 4199.

35 Case C-50/00 P Unión de Pequeños Agricultores $v$ Council [2002] ECR I-6677.

36 Case C-50/00 P Unión de Pequeños Agricultores v Council [2002] ECR I-6677, Opinion of AG Jacobs.

37 C Koch, 'Locus Standi of Private Applicants under the EU Constitution: Preserving Gaps in the Protection of Individuals 'Right to an Effective Remedy' [2005] 30 EL Rev 511, 515.

38 Koch (n 37) 515; Ragolle (n 5) 91;Albor-Llorens (n 5) 87.

39 Opinion of AG Jacobs (n 36) para 43. The dilemma for individuals in such situations is explained by Corthaut: 'either [the individual] obeys the regulation in spite of her doubts as to its validity - which may result in unnecessary losses - or she may choose to violate the regulation and hope that her hunch about its invalidity proves correct - if so, she walks free, otherwise little can save her from potentially severe punishment' in T Corthaut, 'Comment on Jégo-Quéré' [2002-2003] 9 Columbia Journal of European Law 141, 143. This situation is what prompted the CFI to relax the test of standing in the Jégo-Quéré case and declare the action admissible. 
The second situation arises when applicants are able to gain access to national courts. For such situations, in the ECJ's view, 'it is for the Member States to establish a system of legal remedies and procedures which ensure respect for the right to effective judicial protection' ${ }^{40}$

However, several problems can be observed with regard to the ECJ's reliance on national courts as a correct forum for cases in which the validity of EU legislation is in question, such as the fact that the preliminary reference procedure is not available to applicants as a matter of right, since national courts (with the exclusion of courts of last instance) may refuse to refer a question of validity of an EU measure to the ECJ or might err in their assessment of the validity of an EU measure and decline to refer a question to the ECJ on that basis. In addition, even where a reference is made, the preliminary questions are formulated by the national courts, with the consequence that applicants' claims might be redefined or that the questions referred might limit the range of measures whose validity is being challenged before the national court. ${ }^{41}$ Furthermore, proceedings brought before a national court are more disadvantageous for individuals compared to an action for annulment under Article 263 TFEU, since they involve delays and extra costs.

Hence, the argument of the alleged completeness of systems of remedies is not sufficient to escape a violation of Article 9(2) and (3) of the Aarhus Convention.

The question is then whether the recognition of a broader standing for applicants would require a Treaty amendment. Despite the CFI's opinion to the contrary in the Autonomous Region of the Azores case, it can be argued that another interpretation of the criteria laid down in Article 263(4) TFEU is definitely possible and, in fact, required. Nothing in Article 263 suggests that if an applicant is to prove individual concern vis-à-vis a measure of general application, then the person needs to prove that he is differentiated from all other persons in the same way as an addressee. In other words, the Plaumann formula is not contained in the Treaties, but is the European Courts' interpretation of the phrase 'individual concern'. The phrase itself cannot be altered by the ECJ, but changing the interpretation given to it is not something that needs to be left to the Member States, but is the Court's responsibility. ${ }^{42}$

40 Unión de Pequeños Agricultores (n 35) para 41.

41 Opinion of AG Jacobs (n 36) para 42.

42 The ECJ has also used the same 'passing the hot potato back to the Member States' technique in the UPA case, for which it has been criticised by several scholars. See D Chalmers and G Monti European Union Law (4th edn, Cambridge University Press 2006) 433; Ragolle (n 5) 100; T Tridimas and S Poli, 'Locus Standi of Individuals under Article 230(4): the Return of Euridice?' in T Tridimas and S Poli, Making Community Law: The Legacy of Advocate General Francis Jacobs at the European Court of Justice (Edward Elgar Publishing 2008) 77, 


\section{The changes brought by the Lisbon Treaty and the (non-existent) implications for environmental NGOs}

The Treaty of Lisbon modified the standing requirements for non-privileged applicants, thereby dispensing with the need to show individual concern in relation to a regulatory act that does not entail implementing measures. In particular, according to Article 263(4) TFEU:

[A]ny natural or legal person may ... institute proceedings against an act addressed to that person or which is of direct and individual concern to them, and against a regulatory act which is of direct concern to them and does not entail implementing measures.

From an examination of this provision it seems clear that the basic policy underlying the system of judicial review has not been changed: individuals wishing to challenge acts that are not addressed to them still have to prove individual and direct concern. ${ }^{43}$ The relaxation of the standing rules will only apply to situations in which two requirements are met: first, when the measure under challenge is a regulatory act, and second, when the measure in question does not entail implementing measures.

These changes, however, have not had the effect of bringing the EU into compliance with its obligations under the Aarhus Convention, and the added wording does not significantly change the present situation for environmental NGOs.

In order to assess the potential impact of this change, the meaning of the phrase 'regulatory act' must be explained first. The phrase 'regulatory act' is, like the amendment itself, a leftover from the Constitutional Treaty, ${ }^{44}$ although no definition of a 'regulatory act' can be found in either the Constitutional Treaty or the Treaty of Lisbon. ${ }^{45}$ However, in the light of the distinction made between legislative acts ${ }^{46}$ and non-legislative

81; Albor-Llorens (n 5), 90; Abaquense (n 4)387. On this point and specifically with regard to the compliance by the EU with its obligations stemming from the Aarhus Convention, see M Pallemaerts, 'Compliance by the European Community with its Obligations on Access to Justice as a Party to the Aarhus Convention'(Institute for European Environmental Policy, 2009) 41.

43 Lewis (n 4) 1532.

44 The Convention for the Future of Europe took the view that a relaxation of the test of individual concern would be desirable. See Final Report of Discussion Circle CONV 636/03. This relaxation was later introduced in Article III-270(4) of the Constitutional Treaty. For a detailed account of the alternatives considered by the Discussion Circle, see R Barents, "The Court of Justice in the Draft Constitution' [2004] 11Maastricht Journal of European and Comparative Law 121, 130.

45 Koch regards this omission as regrettable, especially because it concerns 'a provision which directly impacts on private parties' procedural rights'. Koch (n 37) 520.

46 According to Article 289(3) TFEU, a legislative act is an act adopted in accordance with a legislative procedure, either the ordinary procedure or a special legislative procedure. 
acts of general application, ${ }^{47}$ the latter acts can be generally regarded as 'regulatory acts' within the meaning of Article 263(4). ${ }^{48}$ These acts can thus certainly be implementing and delegated regulations adopted under Articles 290 and 291(2) TFEU and possibly also decisions of general application. ${ }^{49}$ It is more doubtful, however, whether 'regulatory acts' also include regulations that are adopted through a legislative procedure. ${ }^{50}$

Furthermore, the locus standi of individual applicants is broadened only with regard to regulatory acts which do not require implementing measures, that is, when the applicant could only obtain access to justice by breaching the provisions of the contested measure and invoking its invalidity as a defence in criminal or administrative proceedings against him before a national court.

Many environmental measures fall outside the scope of the concept of a 'regulatory act which does not entail implementing measures'.

First of all, a great part of EU environmental measures are adopted in the form of directives. These are acts which, regardless of their legislative or non-legislative nature, by definition entail implementing measures and thus will not be included in the measures for which, according to Article 263(4) TFEU, individual concern does not need to be proven.

Secondly, even where the environmental measure is adopted by way of a decision (which was the case in the Greenpeace and EEB cases discussed above), the situation is not significantly improved for environmental NGOs. This is because the new wording of Article 263 TFEU, read in conjunction with Article 289(3) TFEU, seems to preclude application to the Court against all decisions which were adopted by way of a legislative procedure. All decisions which are adopted by legislative procedure constitute 'legislative acts', and therefore cannot be challenged under the new wording in Article 263 TFEU. Furthermore, in the case of adoption by way of a non-legislative procedure, many decisions could still not be challenged in court under Article $263 \mathrm{TFEU}$, because they would either not qualify as regulatory acts because of a lack of general application, or because they need implementing measures at the EU or Member State level.

Finally, where a regulation is used to issue a measure which has an effect on the environment (which was the case in the WWF-UK and

\footnotetext{
47 According to Article 290(1) TFEU, 'a legislative act may delegate to the Commission the power to adopt non-legislative acts of general application to supplement or amend certain non-essential elements of the legislative act'.

48 C Brown and J Morijn, 'Comment on Jégo-Quéré' [2004] 41CML Rev 1639, 1655.

49 Koch (n 37) 519-521.

50 For a further discussion on this topic, see S Balthasar, 'Locus Standi Rules for Challenges to Regulatory Acts by Private Applicants: The New Article 263(4) TFEU' [2010] 35 EL Rev 542 .
} 
Autonomous Region of the Azores cases discussed above), the loosening of the standing requirements will only take place where the regulation is not adopted by legislative procedure and does not entail implementing measures. However, where regulations and decisions are used in the environmental field, they tend to entail a considerable number of implementing measures such as the designation of national competent authorities, the issuing of permits by national authorities, and the monitoring of respect for the provisions by the national authorities. ${ }^{51}$ They are therefore normally not directly applicable, but require implementing provisions to be adopted by EU institutions or the Member States.

In conclusion, one could argue that the new wording of Article 263 TFEU will only affect a small number of measures and actions taken by EU institutions or bodies. As the new text only refers to provisions of regulatory acts which do not need implementation measures, it is not likely that a significant number of EU measures that affect the environment could be challenged under the new provision. The EU courts' (to date limited) interpretation of this provision does not seem to alter this conclusion.

In Arcelor, for example, the applicant challenged a directive establishing a scheme for greenhouse gas emission allowance trading within the Community. ${ }^{52}$ The General Court argued, among other things, that the Directive could not in any event, be regarded as being a regulatory act which does not entail implementing measures within the terms of the fourth paragraph of Article 263 TFEU ${ }^{53}$ because the Member States have a broad discretion with regard to implementation of the measure. In this ruling, therefore, the accent is not so much on the scope of the concept of 'regulatory act', but rather on the fact that if there are implementing measures, which is bound to be the case with directives, individual concern will always have to be shown.

The issue was raised again and became of particular significance in Inuit, in which the applicants were seeking the annulment of a regulation concerning the trade in seal products and interim measures in the form of an order of suspension of the operation of the regulation itself. ${ }^{54}$ In deciding on whether to grant the interim measures requested, the President of the General Court observed that the admissibility of the action of annulment could not be excluded, because it was unclear whether the regulation at stake would qualify as a 'regulatory act', and what the con-

51 Jans (n 9) 485.

52 Case T-16/04 Arcelor v European Parliament and Council [2010] OJ C-100/35.

53 Arcelor (n 52) para 123.

54 Case T-18/10 R Inuit Tapiriit Kanatami and Others $v$ European Parliament and Council [2010] OJ C-161/41. 
cept of 'implementing measures' for the purposes of Article 263(4) TFEU entailed. ${ }^{55}$

\section{Conclusion}

It is the ECJ itself which has stated, in a certainly less known passage of its Plaumann ruling, that 'P $\mathrm{P}]$ rovisions of the Treaty regarding the right of action of interested parties must not be interpreted restrictively ... the Treaty being silent on this point, a limitation in this respect may not be presumed'. ${ }^{56}$ The analysis carried out above shows, however, that by applying the restrictive Plaumann test to the actions brought by environmental NGOs, the European courts have, to date, significantly curtailed access to justice to challenge EU measures affecting the environment. In fact, in none of the cases brought at the European level have environmental NGOs ever been granted standing.

It has also been shown that the Lisbon Treaty is unlikely to bring any significant change to the current situation, given the scope of the concept of 'regulatory act which does not entail implementing measures', which is not likely to encompass many of the environmental measures which could possibly constitute the subject matter of an action for annulment brought by NGOs.

This jurisprudence established by the ECJ (coupled with the lack of improvements brought by the Lisbon Treaty for environmental NGOs) seems to be too strict to meet the criteria of the Aarhus Convention, as was also recently established by the Aarhus Compliance Committee in its Findings. ${ }^{57}$ While it is true that none of the cases discussed above was initiated after the entry into force of the Aarhus Regulation, it can hardly be imagined that, with the entry into force of the Regulation, a dramatic change in the case law of the European courts may be expected. On the other hand, if the examined jurisprudence of the EU Courts on access to

\footnotetext{
55 It must be pointed out that the reasoning of the President is not clear. In paragraph 44, it is argued that in the context of the definition of the scope of the concept of 'regulatory act', 'as the Parliament and the Council point out, that category of act would probably have to be defined in relation to that of "legislative acts", subject to the particular circumstance, in the present case, that Regulation No 1007/2009 was not adopted in accordance with the legislative procedure laid down in Article 294 TFEU'. This line of reasoning is not clear, given the fact that Regulation No 1007/2009 was adopted in accordance with Article 251 EC, which is equivalent to Article 294 TFEU, and that this is exactly what the Parliament and the Council were arguing, as shown by paragraph 32 of the Order.

56 Plaumann (n 13) Part I.

57 Aarhus Compliance Committee, Findings and Recommendations with regard to Communication ACCC/C/2008/32 (Part I) concerning compliance by the European Union, available at <http://www.unece.org/env/pp/compliance/CC-32/ece.mp.pp.c.1.2011.4.add.1.edited. adv\%20copy.pdf>.
} 
justice were to continue, there would be a clear violation of Article 9(2) and (3) of the Convention. ${ }^{58}$

As a different interpretation of 'individual concern' is possible and does not require any Treaty amendment, it is submitted that the European Courts should, in order to comply with the Aarhus Convention, consider the environmental NGOs which fulfil the criteria for entitlement provided by Article 11 of the Aarhus Regulation as being individually concerned for the purposes of bringing an annulment action against EU measures affecting the environment. Whether the European Court will in future interpret Article 263 TFEU more openly remains to be seen.

Should the ECJ not proceed to change the current interpretation of the notion of individual concern, two possible scenarios may be envisaged. The first, in principle more cumbersome, way to allow for a broader standing of environmental NGOs to challenge EU measures would be through a Treaty revision, pursuant to Article 48 TEU, by following the ordinary procedure with a convention, or possibly without one should the European Council decide that such a convention is not necessary. ${ }^{59}$ A paragraph could also be added to Article 263 TFEU to the effect that NGOs which fulfil the requirements of Article 11 of the Aarhus Regulation do not need to prove individual concern.

Alternatively, one could envisage the creation of a specialised court for environmental matters attached to the General Court pursuant to Article 257 TFEU. According to this provision, such a specialised court would have to be set up through a regulation adopted by the European Parliament and the Council, acting in accordance with the ordinary legislative procedure, either upon a proposal of the Commission after consultation with the Court of Justice or at the request of the Court of Justice after consultation with the Commission (which seems to be a less likely alternative). The establishing regulation would give this specialised court jurisdiction for matters falling within the scope of the Aarhus Convention, and would provide for a right of action for environmental NGOs which fulfil the requirements of Article 11 of the Aarhus Regulation.

\footnotetext{
58 However, it must be pointed out that the Committee noted that it considered 'with regret that the EU Courts, despite the entry into force of the Convention, did not account for the fact that the Convention had entered into force' (n 57) para 87.

59 Pursuant to Article 48(3) TEU, if the European Council adopts by a simple majority a decision in favour of examining a Treaty amendment, the President of the European Council has to convene a Convention composed of representatives of the national parliaments, heads of state or governments of the Member States, the European Parliament and the Commission. The Convention shall examine the proposals for amendments and shall adopt by consensus a recommendation to a conference of representatives of the governments of the Member States.
} 
